\section{Root-knot Nematode Resistance in Cucumber and Horned Cucumber}

\author{
S. Alan Walters ${ }^{1}$, Todd C. Wehner ${ }^{2}$, and Kenneth R. Barkel ${ }^{3}$ \\ North Carolina State University, Raleigh, NC 27695-7609
}

Additional index words. Cucumis sativus, C. metuliferus, disease resistance, cucurbit, Meloidogyne incognita, M. arenaria, M. hapla, M. javanica, vegetable breeding

\begin{abstract}
Cucumber (Cucumis sativus L.) and horned cucumber ( $C$. metuliferus Naud.) germplasm were evaluated for their resistance to root-knot nematodes (Meloidogyne spp.). All 24 C. metuliferus cultigens evaluated were resistant to all root-knot nematodes tested$M$. incognita (Kofoid and White) Chitwood race 3, M. arenaria (Neal) Chitwood race 2, and M. hapla Chitwood. All $884 C$. sativus cultigens (cultivars, breeding lines, and plant introduction accessions) tested were resistant to $M$. hapla and few to $M$. incognita race 3 . Only 50 of $884 C$. sativus cultigens evaluated were somewhat resistant to $M$. arenaria race 2 and $M$. incognita race 3. A retest of the most resistant C. sativus cultigens revealed that $\mathbf{L J} 90430$ [an accession of $C$. sativus var. hardwickii (R.) Alef.] and 'Mincu' were the only cultigens that were moderately resistant to $M$. arenaria race 2 . LJ 90430 was the only cultigen, besides the two retested C. metuliferus cultigens, that was resistant to M. javanica (Treub) Chitwood. All $C$. sativus cultigens retested, including LJ 90430, were highly susceptible to $M$. incognita races 1 and 3 . The two $C$. metuliferus cultigens retested were highly resistant to all root-knot nematodes tested- $M$. arenaria race $2, M$. incognita races 1 and 3 , and $M$. javanica.
\end{abstract}

Cucumber is one of the three most important horticultural food crops in North Carolina (North Carolina County Agents' Estimates, 1990). Root knot is the most economically important cucumber disease in North Carolina, causing an average annual yield loss of $11 \%$ (St. Amand and Wehner, 1991). Cucumber is considered to be one of the most susceptible major vegetables to root-knot nematodes (Fassuliotis, 1979). Root knot is predominantly caused by four Meloidogyne species: $M$. incognita,M. arenaria, $M$. javanica, and $M$. hapla (Fassuliotis, 1982). Cucumber cultivars resistant to one or more of those species would be useful to growers by providing disease control with reduced nematicide use. Meloidogyne hapla is not a problem on cucumbers grown in North Carolina, but fieldgrown cucumbers in Canada were significantly damaged by M. hapla (Zimmer and Walkof, 1968).

Much effort has been invested in identifying resistance to root-knot nematodes in many crop species, including cucumber (Fassuliotis, 1979). Forty-two cucumber cultivars were tested by Winstead and Sasser (1956). All

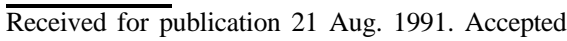
for publication 29 Sept. 1992. The use of trade names in this publication does not imply endorsement by the North Carolina Agricultural Research Service of the products named nor criticism of similar ones not mentioned. This paper is based on a portion of a thesis to bc submitted by S.A.W. in partial fulfillment of the requirements for the MS. The cost of publishing this paper was defrayed in part by the payment of page charges. Under postal regulations, this paper therefore must be hereby marked advertisement solely to indicate this fact.

${ }^{1}$ Former Graduate Assistant, Dept. of Horticultural Science.

${ }^{2}$ Professor, Dept. of Horticultural Science.

${ }^{3}$ Professor, Dept. of Plant Pathology.
}

were resistant to $M$. hapla and susceptible to $M$. incognita, $M$. incognita "acrita," $M$. javanica, and M. arenaria. The U.S. Dept. of Agriculture (USDA) germplasm collection (289 cucumber accessions in 1963) was evaluated by Fassuliotis and Rau (1963). All accessions were susceptible to $M$. incognita "acritu" and were marked by profuse galling and nematode reproduction.

The African homed cucumber is highly resistant to root-knot nematodes. Norton and Granberry (1980) reported that C. metuliferus was highly resistant to the root-knot nematodes $M$. incognita, $M$. arenaria, and $M$. javanica. Wehner et al. (1991) found that $C$. sativus 'Sumter' was more susceptible than $C$. metuliferus to $M$. incognita, $M$. arenaria, and $M$. javanica. Other Cucumis species, including $C$. anguria L., $C$.ficifolius A. Rich., $C$. longipes Hook., and C. heptadactylus Naud., are resistant to Meloidogyne spp. (Fassuliotis, 1967).

Although there has been much progress in selecting and breeding for root-knot resistance in many other important horticultural crops, no progress has been made in cucumber, and attempts to produce viable interspecific hybrids between cucumber and several related resistant wild Cucumis spp. have failed (Fassuliotis, 1979). Successful gene exchange between $C$. sativus and related wild species is difficult using conventional hybridization techniques, since $C$. sativus has a different chromosome number than other related wild Cucumis spp.

Screening methods have been standardized for evaluating root-knot resistance, and several have been useful (Fassuliotis, 1979). Evidence of the existence of races for some Meloidogyne spp. demonstrated a need to reevaluate cultigen response to specific races (Taylor and Sasser, 1978).

The objective of this research was to
Table 1. Origin and resistance of cultigens used in germplasm evaluation for root-knot nematode resistance in Cucumis spp. ${ }^{2}$

\begin{tabular}{|c|c|}
\hline Cultigen & $\begin{array}{c}\text { Cultigen } \\
\text { (no.) }\end{array}$ \\
\hline \multicolumn{2}{|l|}{ Origin } \\
\hline C. sativus & 900 \\
\hline Accessions & 728 \\
\hline Turkey & 170 \\
\hline P.R. China & 93 \\
\hline Yugoslavia & 63 \\
\hline Iran & 59 \\
\hline India $^{y}$ & 46 \\
\hline Japan & 43 \\
\hline Former USSR & 40 \\
\hline Czechoslovakia & 31 \\
\hline Netherlands & 18 \\
\hline USA & 15 \\
\hline Other & 150 \\
\hline Breeding lines ${ }^{y}$ & 36 \\
\hline Cultivars & 136 \\
\hline Current & 17 \\
\hline NSSL & 31 \\
\hline No data obtained & 16 \\
\hline C. metuliferus & 24 \\
\hline Accessions & 24 \\
\hline Zimbabwe & 22 \\
\hline S. Africa & 2 \\
\hline \multicolumn{2}{|l|}{ Resistance } \\
\hline C. sativus & 900 \\
\hline Highly ( $1 \%$ to $10 \%$ root galling) & 2 \\
\hline Moderately (11\% to $20 \%$ root galling) & 1 \\
\hline Slightly ( $21 \%$ to $40 \%$ root galling) & 47 \\
\hline Susceptible ( $>40 \%$ root galling) & 834 \\
\hline C. metuliferus & 24 \\
\hline Highly ( $1 \%$ to $10 \%$ root galling) & 24 \\
\hline Moderately ( $11 \%$ to $20 \%$ root galling) & 0 \\
\hline Slightly ( $21 \%$ to $40 \%$ root galling) & $\mathbf{0}$ \\
\hline Susceptible ( $>40 \%$ root galling) & $\mathbf{0}$ \\
\hline
\end{tabular}

${ }^{{ }^{2}}$ Cultivars and breeding lines were obtained from cucumber breeders and commercial seed companies; plant introduction accessions from the Regional Plant Introduction Station, Ames, Iowa; and old cultivars from the National Seed Storage Lab. (NSSL), Fort Collins, Colo. Cultigen resistance is based on data obtained from Meloidogyne incognita race 3 and $M$. arenaria race 2.

Included is LJ 90430 (a breeding line of $C$. sativus var. hardwickii).

evaluate the $C$. sativus and $C$. metuliferus germplasm collection for resistance to three root-knot nematode species-M. incognita race $3, M$. arenaria race 2 , and $M$. hapla. The most resistant and susceptible cultigens from the initial screening [ 14 plant introduction (PI) accessions, 12 cultivars, and 6 breeding lines of $C$. sativus and 2 PI accessions of $\mathrm{C}$. metuliferus] were retested for resistance to 4 root-knot nematodes- $M$. incognita race $1, M$. incognita race $3, M$. arenaria race 2, and $M$. javanica.

Two greenhouse experiments were conducted: a germplasm evaluation and a retest of the most resistant or susceptible 34 cultigens.

Evaluating the germplasm collection. A greenhouse experiment was conducted to evaluate 924 cultigens for resistance to three species of root-knot nematodes- $M$. incognita race $3, M$. arenaria race 2 , and $M$. hapla. Thirty-six breeding lines, 136 cultivars, and $728 \mathrm{PI}$ accessions of $C$. sativus and $24 \mathrm{PI}$ accessions of $C$. metuliferus were tested. Old cultivars were obtained from the National Seed 
Storage Laboratory (NSSL), Fort Collins, Colo., new cultivars from seed companies, and breeding lines from state experiment stations. PI accession seeds were obtained from the North Central Plant Introduction Station, Ames, Iowa, originally collected from diverse locations around the world (Table 1).

In our tests, all $C$. sativus and $C$. metuliferus plants were grown from seed in $15 \mathrm{~cm}$-diameter (1.8 liter) clay pots on benches in a greenhouse. Five seeds of each cultigen were sown in pots containing a 1 sand : 1 soil $(\mathrm{v} / \mathrm{v} ; 85 \%$ sand, $10 \%$ silt, $5 \%$ clay) steam-sterilized mixture. Plants were thinned to two per pot at the twoleaf stage and to one per pot at the three-leaf stage. Fertilizer ( $200 \mathrm{mg} \mathrm{N} / \mathrm{kg}$ ) was supplied twice daily by drip irrigation. Greenhouse temperatures averaged $35 \mathrm{C}$ day/27C night.

Meloidogyne incognita race $3, M$. arenaria race 2 , and $M$. hapla populations were maintamed in the greenhouse on tomato ( Lycopersicon esculentum L. 'Rutgers') for use as inoculum. Inoculum was prepared using Hussey and Barker's technique (1973) and was standardized to $200 \mathrm{eggs} / \mathrm{ml}$ of water, so that $25 \mathrm{ml}$ of suspension would contain $\approx 5000$ eggs. A 25-ml suspension of eggs was poured on the soil around the base of each plant. After all plants had been inoculated, each pot was topped with $13 \mathrm{~mm}$ of moist potting medium to protect eggs from desiccation.

Root-knot nematode damage was determined on washed roots (Nijs and Hofman, 1983) 9 weeks after inoculation (11 weeks after planting) using the gall index system $(0 \%$ to $100 \%$ of roots covered with galls) (Barker et al., 1986). The gall index system was a modification of that used by Taylor and Sasser (1978). Percentage of galled roots was used to determine resistance as follows: $0 \%=$ immune, $1 \%$ to $10 \%$ = highly resistant, $11 \%$ to $20 \%=$ moderately resistant, $21 \%$ to $40 \%=$ slightly resistant, and $>40 \%=$ susceptible.

The experiment was a split-plot treatment arrangement in a randomized complete-block design with three replications for $M$. incognita race 3 and M. arenaria race 2 and one replicate for M. hapla. Whole plots were the three nematode species, and subplots were the 924 cultigens. Data were subjected to analysis of variance using SAS (SAS Inst., Cary, N.C.), and cultigen means were tested using Fisher's least significant difference (LSD).

Retesting the extreme cultigens. In the second experiment, we verified results from Expt. 1 using the most resistant or susceptible 34 Cucumis cultigens (14 accessions, 12 cultivars, and 6 breeding lines of $C$. sativus and 2 PI accessions of $C$. metuliferus) for resistance to four root-knot nematodes $(M$. incognita race $1, M$. incognita race $3, M$. arenaria race 2, and $M$. javanica).

The experiment was conducted in a greenhouse at $\approx 35 \mathrm{C}$ day/24C night. The same procedures and cultural practices were followed as in Expt. 1.

Roots were rated 11 weeks afterplanting (9 weeks after inoculation) using the gall index system as described for Expt. 1, after which egg masses on roots were stained red with phloxine B (Hartman and Sasser, 1985). Egg

Table 2. Root-knot nematode resistance (percent galls) in selected Cucumis cultigens evaluated with three species of Meloidogyne in the germplasm evaluation experiment. Cultigens ranked in order by resistance. ${ }^{2}$

\begin{tabular}{|c|c|c|c|c|c|c|}
\hline \multirow[b]{2}{*}{ Rank } & \multirow[b]{2}{*}{ Cultigen } & \multirow[b]{2}{*}{ Origin } & \multicolumn{4}{|c|}{ Roots affected (\%) } \\
\hline & & & Mean & $\mathrm{Ma} 2$ & $\mathrm{Mi3}$ & $\overline{\mathrm{Mh}}$ \\
\hline
\end{tabular}

\begin{tabular}{|c|c|c|}
\hline \multirow{2}{*}{\multicolumn{3}{|c|}{ Resistant }} \\
\hline & & \\
\hline 1 & Green Thumb ${ }^{y}$ & Harris Seed \\
\hline 2 & PI $482454^{x}$ & Zimbabwe \\
\hline 3 & PI $482456^{x}$ & Zimbabwe \\
\hline 4 & PI 482449 & Zimbabwe \\
\hline 5 & PI $482450^{x}$ & Zimbabwe \\
\hline 6 & PI $482440^{x}$ & Zimbabwe \\
\hline 7 & PI $482442^{x}$ & Zimbabwe \\
\hline 8 & PI 482453x & Zimbabwe \\
\hline 9 & PI $482452^{x}$ & Zimbabwe \\
\hline 10 & PI 482444x & Zimbabwe \\
\hline 11 & PI $482439^{x}$ & Zimbabwe \\
\hline 12 & PI $482455^{x}$ & Zimbabwe \\
\hline 13 & Southern Pickler & Arkansas AES \\
\hline 14 & PI $482446^{x}$ & Zimbabwe \\
\hline 15 & PI $292190^{x}$ & South Africa \\
\hline 16 & PI $482458^{x}$ & Zimbabwe \\
\hline 17 & PI $482451^{x}$ & Zimbabwe \\
\hline 18 & PI $202681^{x}$ & South Africa \\
\hline 19 & Pl $482460^{x}$ & Zimbabwe \\
\hline 20 & PI $482461^{x}$ & Zimbabwe \\
\hline 21 & PI $482459^{x}$ & Zimbabwe \\
\hline 22 & PI $482443^{x}$ & Zimbabwe \\
\hline 23 & PI $482435^{x}$ & Zimbabwe \\
\hline 24 & PI $482441^{x}$ & Zimbabwe \\
\hline 25 & PI 482448x & Zimbabwe \\
\hline 26 & PI $482462^{x}$ & Zimbabwe \\
\hline
\end{tabular}

\section{Moderately resistant}

$$
\begin{aligned}
& 27 \\
& \text { Slightly resistant }
\end{aligned}
$$

28
29
30

30

31
32

32
33
34

34

35

36
37

37
42

60

Susceptible

90

245

267

276

289
340

340
343

343
374

395

407

419

443

445

512

515

615

632

665

709

845

894
895

895
896

896
897

898

899

900

901
902
LJ 90430

PI $261608^{y, v}$

PI 422186

PI $211975^{y, v}$

PI $368560^{y, v}$

PI $292012^{v}$

PI $432867^{\mathrm{y}, \mathrm{v}}$

PI 249550y

PI $167043^{v}$

PI $436610^{v}$

Mincu $^{v}$

Delcrow ${ }^{\mathrm{y}, \mathrm{v}}$

Gy $4^{y, v}$

M 41 $1^{y, v}$

Producer

Sumter ${ }^{y}$

Dharampur-I ${ }^{\mathrm{y}}$

Double Yield ${ }^{v}$

Poinsett ${ }^{*}$

H-19y

Gy $14 A^{y}$

M 21

Sprint 440

Slice $^{y, v}$

Wisconsin SMR 12

Sumter ${ }^{y}$

Dasher II

Marketmore 76

Wisconsin SMR 18

Calypso

Poinsett 76

Clinton

Sumter

PI 137836

PI 357859

PI 178884

PI 368551

PI 264667

PI 308915

PI 179260

Early Cluster

PI 192940
USDA, La Jolla, Calif.

Spain

Czechoslovakia

Iran

Yugoslavia

Israel

P.R. China

Iran

Turkey

P.R. China

Minnesota AES ${ }^{u}$

NSSL

N.C. State Univ.

N.C. State Univ.

NSSL

Clemson Univ.

Nepal

NSSL

Clemson Univ.

Arkansas AES

N.C. State Univ.

N.C. State Univ.

Asgrow Seed

Clemson Univ.

Wisconsin $\mathrm{AES}^{\mathrm{s}}$

Clemson Univ.

PetoSeed

Comell Univ.

Wisconsin AES

N.C. State Univ.

Cornell Univ.

N.C. State Univ.

Clemson Univ.

Iran

Yugoslavia

Turkey

Yugoslavia

Germany

Former USSR

Turkey

NSSL

P.R. China

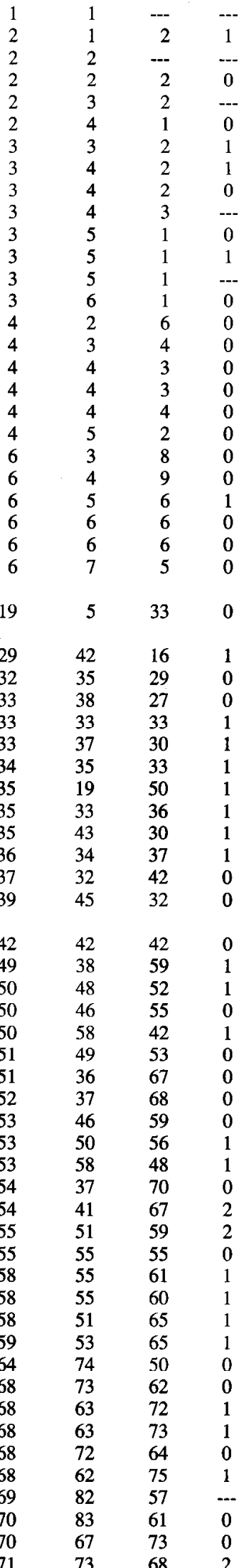




\begin{tabular}{rlllccc}
\hline & & & \multicolumn{3}{c}{ Roots affected (\%) } \\
\cline { 3 - 7 } Rank & \multicolumn{1}{c}{ Cultigen } & \multicolumn{1}{c}{ Origin } & Mean & Ma2 & Mi3 & Mh \\
\hline 903 & PI 257487 & P.R. China & 71 & 64 & 78 & 0 \\
904 & PI 169328 & Turkey & 71 & 71 & 71 & 1 \\
905 & Tiny Dill & New Hampshire & 72 & 70 & 75 & 1 \\
906 & PI 264228 & France & 75 & 75 & -- & -- \\
907 & PI 182192 & Turkey & 78 & 78 & --- & 0 \\
908 & Black Diamond & Hollar Seed & 87 & --- & 87 & -- \\
\hline
\end{tabular}

${ }^{2}$ Data are means of three replications of one plant each for $M$. arenaria race $2(\mathrm{Ma} 2)$ and $M$. incognita race 3 (Mi3), but for $M$. hapla $(\mathrm{Mh})$, data are from one replication of one plant each, since all cultigens evaluated were resistant. Only $M$. arenaria race 2 and $M$. incognita race 3 are used in the computation of the overall mean. Gall index represents percentage of root system damaged by nematode galls. Resistance ratings based on overall gall index: $1 \%$ to $10 \%=$ resistant, $11 \%$ to $20 \%=$ moderately resistant, $21 \%$ to $40 \%=$ slightly resistant, and $>40 \%=$ susceptible.

'Escape observed for $M$. arenaria race 2.

${ }^{x}$ Accession of $C$. metuliferus.

"Arkansas AES = Arkansas Agricultural Expt. Station, Fayetteville.

'Escape observed for $M$. incognita race 3 .

"Minnesota AES = Minnesota Agricultural Expt. Station, St. Paul.

NSSL = National Seed Storage Lab., Fort Collins, Colo.

${ }^{s}$ Wisconsin AES = Wisconsin Agricultural Expt. Station, Madison.

Table 3. Root-knot nematode resistance (percent galls) from retest study in which 34 Cucumis cultigens were evaluated against four species of Meloidogyne. ${ }^{2}$

\begin{tabular}{|c|c|c|c|c|c|c|c|}
\hline \multirow[b]{2}{*}{ Rank } & \multirow[b]{2}{*}{ Cultigen } & \multirow[b]{2}{*}{ Origin } & \multicolumn{5}{|c|}{ Roots affected (\%) } \\
\hline & & & Mean & $\mathrm{Ma}^{2}$ & $\mathrm{Mi1}^{y}$ & $\mathrm{Mi3}^{\mathrm{y}}$ & $\mathrm{Mj}^{\mathrm{y}}$ \\
\hline 1 & PI $482452^{x}$ & Zimbabwe & 5 & 2 & 7 & 4 & 5 \\
\hline 2 & PI 482443x & Zimbabwe & 6 & 5 & 5 & 6 & 7 \\
\hline 3 & LJ 90430 & USDA, La Jolla, Calif. & 29 & 11 & 55 & 44 & 8 \\
\hline 4 & Southern Pickler & Arkansas AES ${ }^{w}$ & 54 & 23 & 59 & 69 & 63 \\
\hline 5 & Mincu & Minnesota $\mathrm{AES}^{\vee}$ & 55 & 18 & 75 & 64 & 63 \\
\hline 6 & Ohio MR 17 & Ohio AES ${ }^{u}$ & 60 & 39 & 72 & 62 & 66 \\
\hline 7 & Producer & NSSL $^{t}$ & 60 & 26 & 71 & 77 & 67 \\
\hline 8 & Gy 4 & N.C. State Univ. & 61 & 43 & 65 & 68 & 66 \\
\hline 9 & Poinsett & Clemson Univ. & 62 & 39 & 76 & 69 & 65 \\
\hline 10 & Dharampur-I & Nepal & 62 & 43 & 73 & 71 & 62 \\
\hline 11 & M 41 & N.C. State Univ. & 63 & 51 & 73 & 69 & 59 \\
\hline 12 & PI 220169 & Afghanistan & 63 & 57 & 64 & 68 & 63 \\
\hline 13 & PI 432864 & Japan & 64 & 53 & 72 & 74 & 55 \\
\hline 14 & Sumter & Clemson Univ. & 64 & 57 & 69 & 70 & 58 \\
\hline 15 & PI 344350 & Turkey & 64 & 50 & 72 & 70 & 65 \\
\hline 16 & Wisconsin SMR 18 & Wisconsin AES ${ }^{s}$ & 65 & 51 & 74 & 70 & 65 \\
\hline 17 & National Pickling & NSSL & 65 & 56 & 70 & 74 & 61 \\
\hline 18 & Nepal Local 7 & Nepal & 66 & 60 & 73 & 69 & 60 \\
\hline 19 & Chinese Long Green & NSSL & 66 & 54 & 75 & 73 & 63 \\
\hline 20 & Early Russian & NSSL & 66 & 56 & 79 & 67 & 63 \\
\hline 21 & PI 211975 & Iran & 66 & 65 & 69 & 68 & 63 \\
\hline 22 & Delcrow & NSSL & 67 & 54 & 75 & 69 & 68 \\
\hline 23 & PI 176953 & Turkey & 67 & 61 & 76 & 67 & 63 \\
\hline 24 & PI 483342 & P.R. China & 67 & 56 & 74 & 71 & 67 \\
\hline 25 & PI 326594 & Hungary & 67 & 65 & 70 & 59 & 74 \\
\hline 26 & PI 206425 & Turkey & 68 & 58 & 72 & 76 & 64 \\
\hline 27 & PI 308915 & Former USSR & 68 & 52 & 77 & 78 & 64 \\
\hline 28 & PI 478364 & P.R. China & 68 & 63 & 73 & 70 & 66 \\
\hline 29 & PI 319216 & Egypt & 69 & 58 & 76 & 71 & 70 \\
\hline 30 & PI 357865 & Yugoslavia & 69 & 63 & 74 & 71 & 69 \\
\hline 31 & Double Yield & NSSL & 71 & 61 & 74 & 76 & 72 \\
\hline 32 & PI 261608 & Spain & 71 & 61 & 78 & 74 & 72 \\
\hline 33 & PI 169351 & Turkey & 72 & 60 & 77 & 77 & 72 \\
\hline 34 & Green Thumb & Harris Seed & 73 & 63 & 79 & 77 & 74 \\
\hline Mean & & & 60 & 48 & 64 & 66 & 60 \\
\hline $\operatorname{LSD}(5 \%)$ & & & 10 & 12 & 9 & 10 & 10 \\
\hline $\mathrm{cv}(\%)$ & & & 14 & 21 & 10 & 13 & 13 \\
\hline
\end{tabular}

${ }^{2}$ Data for each root-knot nematode species or race are gall index means of five replications of one plant each. Mean is the gall index mean of all root-knot nematodes for each cultigen and represents the resistance rating. Gall index represents percentage of root system containing nematode galls. Resistance ratings based on overall gall index: $1 \%$ to $10 \%=$ resistant, $11 \%$ to $20 \%=$ moderately resistant, $21 \%$ to $40 \%=$ slightly resistant, and $>40 \%=$ susceptible.

${ }^{\mathrm{y}} \mathrm{Ma} 2=M$. arenaria race $2, \mathrm{Mi} 1=M$. incognita race $1, \mathrm{Mi} 3=M$. incognita race 3 , and $\mathrm{Mj}=M$. javanica . ${ }^{x}$ Accession of $C$. metuliferus.

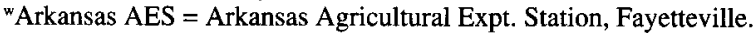

${ }^{\vee}$ Minnesota AES = Minnesota Agricultural Expt. Station, St. Paul.

"Ohio AES = Ohio Agricultural Expt. Station, Columbus.

NSSL = National Seed Storage Lab., Fort Collins, Colo.

${ }^{s}$ Wisconsin AES $=$ Wisconsin Agricultural Expt. Station, Madison. masses were counted using Hadisoeganda and Sasser's method (1982). The egg index system used was a modification of that used by Sasser et al. (1984). Percentage of roots covered with egg masses was used to determine resistance as follows: $0 \%=$ immune, $1 \%$ to $10 \%=$ resistant, $11 \%$ to $50 \%=$ moderately resistant, and $>50 \%=$ susceptible.

The experiment was a split-plot treatment arrangement in a randomized complete-block design with five replications. Whole plots were the four nematodes and subplots were the 34 cultigens. Gall index and egg mass data were analyzed using SAS's GLM and CORR procedures. Cultigen and nematode means were tested using Fisher's LSD.

Evaluating the germplasm collection. All Cucumis cultigens evaluated were highly resistant to $M$. hapla, with little difference in root galling from the most (C. metuliferus) to the least resistant ( $C$. sativus) cultigens.

Selected cultigens evaluated, including the most root-knot resistant, the most susceptible, and current cultivars, are listed in Table 2. The complete data set will be entered into the Germplasm Resources Information Network (USDA, Washington, D.C.).

All C. metuliferus accessions evaluated were found to be highly resistant (1\% to $10 \%$ of roots galled) to all root-knot nematodes tested (Table 2). Those data confirm the work of others (Fassuliotis, 1967,1970; Norton and Granberry, 1980; Wehner et al., 1991), who showed that $C$. metuliferus was resistant to the Meloidogyne spp. causing root knot. However, introducing resistance into C. sativus from $C$. metuliferus may be difficult due to cross incompatibilities.

Only four C. sativus cultigens ('Southern Pickler', LJ90430, PI249550, and PI401733) were highly or moderately resistant to $M$. arenaria race 2, and 108 (e.g., SC 10, 'Delcrow', and 'Mincu') were slightly resistant to $M$. arenaria race 2 . Most cultigens evaluated were susceptible (768 of 881). The most susceptible cultigen was PI 179260 (83\% of roots galled). For $M$. arenaria race 2 , data were not obtained for 19 cultigens due to seed germination or plant growth problems.

Seven $C$. sativus cultigens ('Southern Pickler', PI 220169, PI 357865, PI 261608, PI 226510, PI 137848, and PI 432848) were highly or moderately resistant to $M$. incognita race 3. About 100 cultigens (e.g., Gy 4, LJ 90430 , and 'Mincu') were slightly resistant to $M$. incognita race 3. Most cultigens evaluated (766 of 878) were susceptible to $M$. incognita race 3. 'Black Diamond' was the most susceptible ( $87 \%$ of roots galled). No data were obtained for 22 cultigens for $M$. incognita race 3 resistance.

Most $C$. sativus cultigens were susceptible to the root-knot nematodes tested, with a mean for $M$. arenaria race 2 and $M$. incognita race 3 of $52 \%$ of roots with galls. Some cultigens differed in resistance to the two nematodes, however. For example, PI 220169 had an average gall index of $68 \%$ for $M$. arenaria race 2 and $8 \%$ for $M$. incognita race 3 . Considering both nematodes, no data were collected for 16 cultigens; of the 884 cultigens evaluated, 834 
were susceptible (94\%). 'Tiny Dill' was the most susceptible cultigen overall $(72 \%$ of roots galled). Only two cultigens were highly resistant ('Southern Pickler' and LJ 90430). 'Southern Pickler' was the most resistant cultigen overall $(5 \%$ of roots galled by $M$. arenaria race 2 , and $1 \%$ by $M$. incognita race $3)$. Forty-seven cultigens were slightly resistant to root knot.

Retesting the extreme cultigens. The two C. metuliferus cultigens reevaluated (PI 482452 and PI 482443) were highly resistant to all nematodes, with a mean of $5 \%$ and $6 \%$ of roots galled, respectively (Table 3 ). The $C$. sativus cultigen most resistant to all nematode species was LJ 90430 , with $29 \%$ of its roots galled. [LJ 90430 is an accession of C. sativus var. hardwickii (R.) Alef.] LJ 90430 was highly resistant to $M$. javanica, as were the two $\mathrm{C}$. metuliferus cultigens (Table 3). LJ 90430 was moderately resistant to $M$. arenaria race $2(11 \%$ of roots galled), but was susceptible to $M$. incognita races 1 and 3 . The two $C$. metuliferus cultigens had the fewest egg masses per plant, a result that indicated high resistance, not immunity. LJ 90430 had fewer egg masses per plant than either of the $C$. metuliferus cultigens for $M$. javanica and an average of three egg masses per plant for $M$. arenaria race 2 .

The $C$. sativus cultigens that were slightly resistant in the germplasm evaluation experiment were not resistant in the retest experiment. All were susceptible, considering both the percentage of roots galled and number of egg masses. For example, PI 211975 was resistant to $M$. incognita race 3 in the germplasm evaluation experiment but not in the retest experiment.

Two cultigens chosen from the germplasm evaluation for $M$. arenuriu race 2 resistance'Delcrow' and Nepal Local 7-were susceptible, with $54 \%$ and $60 \%$ of their roots galled, respectively. PI 308915, chosen as the most susceptible cultigen in the first study to $M$. urenaria race 2 , was not the most susceptible cultigen in the retest experiment. Twenty cultigens had a higher percentage of root galls, and 10 cultigens had more egg masses. The cultigens that were chosen for overall susceptibility in the germplasm evaluation (Dharampur-I, PI 483342, and PI 169351) were susceptible to all four root-knot nematodes in the retest.

Several C. sativus cultigens were somewhat resistant to M. arenaria race 2 (LJ 90430,
'Mincu', 'Southern Pickler', 'Producer', 'Ohio MR 17', and 'Poinsett'). LJ90430 and 'Mincu' were moderately resistant, and all others were slightly resistant. 'Southern Pickler' and some of its parental lines, 'Mincu' and 'Producer', were moderately resistant to $M$. urenuriu race 2 , possibly indicating a common genetic basis for resistance.

Of 32 C. sativus cultigens evaluated, 31 were susceptible to $M$. javanica (Table 3 ), including several important cultivars and breeding lines ('Poinsett', 'Sumter', Wisconsin SMR 18, and Gy 4). LJ 90430 was the only resistant C. sativus cultigen ( $8 \%$ of roots galled). Its high level of resistance was not significantly different from that of the $C$. metuliferus cultigens (Table 3 ).

None of the C. sativus cultigens evaluated were resistant to either of the $M$. incognita races tested, with at least $40 \%$ of the roots galled and at least 50 egg masses. LJ 90430 was the least susceptible (55\% and $44 \%$ of roots galled for $M$. incognita races 1 and 3, respectively), but the presence of large numbers of egg masses (1120 and 352 for M. incognita races 1 and 3 , respectively) indicated no resistance to $M$. incognita.

In conclusion, all $C$. metuliferus cultigens were resistant to root-knot nematodes, and $\mathrm{LJ}$ 90430 was the most resistant $C$. sativus cultigen to those species of root-knot nematodes evaluated. The inheritance of the resistance in LJ 90430 remains to be determined.

\section{Literature Cited}

Barker, K.R., J.L. Townshend, G.W. Bird, I.J. Thomason, and D.W. Dickson. 1986. Determining nematode population responses to control agents, p. 283-287. In: K.D. Hickey (ed.). Methods for evaluating pesticides for control of plant pathogens. APS, St. Paul, Minn.

Fassuliotis, G. 1967. Species of Cucumis resistant to the root-knot nematode, Meloidogyne incognita acrita. Plant Dis. Rptr. 51:720-723.

Fassuliotis, G. 1970. Resistance of Cucumis spp. to the root-knot nematode, Meloidogyne incognita acrita. J. Nematol. 2:174-178.

Fassuliotis, G. 1979. Plant breeding for root-knot nematode resistance, p. 425-453. In: J.N. Sasser and C.C. Carter (eds.). Root-knot nematodes (Meloidogyne species): Systematics, biology and control. Academic, New York.

Fassuliotis, G. 1982. Plant resistance to root-knot nematodes, p. 31-49. In: R.D. Riggs (ed.). Nematology in the southern region of the United
States. Arkansas Agr. Expt. Sta., Fayetteville, South. Coop. Serv. Bul. 276.

Fassuliotis, G. and G.J. Rau. 1963. Evaluation of Cucumis spp. for resistance to the cotton rootknot nematode, Meloidogyne incognita acrita. Plant Dis. Rptr. 47:809.

Hadisoeganda, W.W. and J.N. Sasser. 1982. Resistance of tomato, bean, southern pea, and garden pea cultivars to root-knot nematodes based on host suitability. Plant Dis. 66(2):145-150.

Hartman, K.M. and J.N. Sasser. 1985. Identification of Meloidogyne species on the basis of differential host test and perineal-pattern morphology, p. 69-77. In: K.R. Barker, C.C. Carter, and J.N Sasser (eds.). Advanced treatise on Meloidogyne. vol. II: Methodology. Coop. Publ. Dept. Plant Pathol. and U.S. Agency Intl. Dev. North Carolina State Univ. Graphics, Raleigh.

Hussey, R.S. and K.R. Barker. 1973. A comparison ofmethods of collecting inocula of Meloidogyne spp., including a new technique. Plant Dis. Rptr. 12:1025-1028.

Nijs, A.P.M. den and K. Hofman. 1983. Anefficient procedure to screen for resistance to root-knot nematodes in cucurbits. Cucurbit Genet. Coop. Rpt. 6:96-98.

North Carolina County Agents' Estimates. 1990 Horticultural crop estimates in North Carolina. Dept. Hort. Sci., North Carolina State Univ., Raleigh.

Norton, J.D. and D.M. Granberry. 1980. Characteristics of progeny from an interspecific cross of Cucumis melo with Cucumis metuliferus. J. Amer. Soc. Hort. Sci. 105:174-180.

St. Amand, P.C. and T.C. Wehner. 1991. Crop loss to 14 diseases in cucumber in North Carolina for 1983 to 1988. Cucurbit Genet. Coop. Rpt. 14:1517.

Sasser, J.N., C.C. Carter, and K.M. Hartman. 1984. Standardization of host suitability studies and reporting of resistance to root-knot nematodes. Coop. Publ. Dept. Plant Pathol., North Carolina State Univ., and U.S. Agency Intl. Dev., Raleigh.

Taylor, A.L. and J.N. Sasser. 1978. Biology, identification and control of root-knot nematodes (Meloidogyne spp.). Dept. Plant Pathol., North Carolina State Univ., and U.S. Agency Intl. Dev., Raleigh.

Wehner,T.C., S.A. Walters, and K.R. Barker. 1991. Resistance to root-knot nematode in cucumber and homed cucumber. Ann. Applied Nematol. (J. Nematol. 23), Suppl. 23 (4S):611-614.

Winstead, N.N. and J.N. Sasser. 1956. Reaction of cucumber varieties to five root-knot nematodes (Meloidogyne spp.). Plant Dis. Rptr. 40:272275.

Zimmer, R.C. and C. Walkof. 1968. Occurrence of the northern root-knot nematode Meloidogyne hapla on field grown cucumber in Manitoba. Can. Plant Dis. Surv. 48:154. 